„Logopedia Silesiana”, t. 8, ISSN 2391-4297

DOI 10.31261/LOGOPEDIASILESIANA.2019.08.07

(c) BY-SA

JACEK J. BŁESZYŃSKI

Uniwersytet Mikołaja Kopernika w Toruniu

(iD 0000-0002-6553-0550

\title{
Samoocena autyzmu - jak osoby ze spektrum zaburzeń autyzmu odbierają autyzm Badania netnograficzne
}

\begin{abstract}
Autistic Self-perception: How Do the ASD Individuals Perceive Autism? A Netnographic Study

Aвstract: From the times of Leon Kanner, autism was presented as a clinical image of behaviours. The descriptions were as comprehensive as possible, the diagnostic systems and therapies were optimised, and the analyses of various approaches to the etiology of autism were carried out. The contemporary knowledge is founded mainly on the analyses of behaviours, observations, and experiments. Cognition or self-awareness, which is a priority concept in this matter, can also be seen in the objects human beings create: in this case, people diagnosed with autism. The research was conducted at the turn of 2018 and 2019. The aim of the study was acquiring knowledge of autism perception by the individuals who are affected by ASD and able to communicate, according to the age and sex of the respondents. The research was conducted on 168 individuals diagnosed with autism ( 90 women and $78 \mathrm{men}$ ). The innovative aspect of this project lies in using the netnography method for collecting and analysing data. The findings of the research have helped to expand the knowledge of problems that ASD individuals experience and have allowed the subjects of the research to share their own perspectives, including the effect of social labeling on their position in the society.
\end{abstract}

KeY wORDS: self-reflection, autism, autism spectrum disorders

Zainicjowane badania z osobami dorosłymi z diagnozą autyzmu są przedsięwzięciem wielokierunkowymi i wieloetapowym. Mają one na celu dokonanie rewizji dotychczasowej wiedzy na temat tego zaburzenia, jak również podejmowanie optymalnych działań w inkluzji społecznej tej grupy osób. Dokonanie takich analiz stało się realne np. dzięki możliwości prowadzenia badań wśród osób mogących przedstawić swoje doświadczenia (przede wszystkim osób z PDD, wysokofunkcjonujących, jak również komunikujących się), co jest związane z ukształtowaniem się na odpowiednim poziomie świadomości społecznej i kultury inkluzyjnej, która niewątpliwie bazuje na odejściu od klasyfikowania i oceniania w celu plasowania (co niewątpliwie umożliwia nowa klasyfikacja DSM 5, wprowadzając 
opisową charakterystykę stopni ZSA). Równie istotna jest możliwość zastosowania zindywidualizowanych form i metod (bez bezpośredniego kontaktu face to face - z wykorzystaniem wywiadu pogłębionego netnograficznego) zdobywania informacji / materiału badawczego.

Ważna jest zmiana perspektywy podejścia do samego poznania jako procesu pozyskiwania informacji, tj. uświadomienia znaczenia wykorzystania badań jakościowych w poszukiwaniu subiektywnych i zobiektyzowanych koncepcji autyzmu - zaburzenia ze spektrum autyzmu. W tym celu należy odwołać się do ukierunkowanej na poznanie drugiego człowieka filozofii poznania.

\section{Poznanie drugiego - od Edumnda Hursserla do Adama Węgrzeckiego}

Poznanie, wychodząc od założeń przedstawionych przez Edmunda Husserla (1974), jest poszukiwaniem możliwości przekraczania granic psychofizycznego odbicia obrazu w filozofii. Autor ten wskazał dwoistość poznania, iż „[O]statecznym podmiotem fenomenologicznym, który nie podlega żadnemu wyłączeniu i sam jest podmiotem wszelkiego ejdetyczno-fenomenologicznego badania, jest czyste Ja” (s. 247). Poznanie drugiej osoby może opierać się tylko na wczuciu (Einfühlung) jako pośrednim uobecnieniu (s. 281). Jak zaznaczał filozof: „[I]nnych mogę doświadczać, ale tylko przez wczucie, swej własnej treści mogą doświadczać przez źródłową percepcję jedynie oni [...] przeżycia innych są dostępne doświadczeniu przeze mnie jedynie pośrednio - wczuciowo" (s. 283). To podejście jest obarczone dużym subiektywizmem, które Edith Stein (1917, s. 68) zmieniła, zwracając uwagę, iż jako jednostka znajdujemy się we wspólnocie ludzkiej. Tak więc wczucie to rodzaj doświadczenia w bycie przestrzenno-czasowym $\mathrm{z}$ materialnymi procesami i przeżyciami psychicznymi. Właśnie ta perspektywa poszerza pola doświadczania, staje się pogłębionym elementem rozumienia: „[N]ie przez odczucie jedności doświadczamy innych, lecz przez wczuwanie, przez wczucie staje się możliwe odczucie jedności i wzbogacenie własnego przeżywania” (s. 19, tłum. własne). Na tej podstawie jest tworzona świadomość odrębności fizycznej (np. części ciała) i psychicznej (doznań, myśli własnych i innych doznań). Doświadczanie jest sczytywaniem „fenomenów wyrazowych”. To właśnie wczucie pozwala na wniknięcie w akty drugiego człowieka, jego swoistą sferę bytu będąca osobową duchowością.

Max Scheler stworzył teorię poznania, która stanowi obecnie podstawę poznania w naukach humanistycznych. Człowiek, jako byt społeczny, spostrzega drugiego człowieka należącego do swoistej sfery bytu określanej jako „świat Ty (Duwelt)”. To interakcjonizm, który występuje pomiędzy zbiorowością, która kształtuje spo- 
sób przeżywania ludzi wzajemnie. Jak zauważa Adam Węgrzecki (1992): „[W]e wspólnocie życiowej drugi człowiek prezentuje się dzięki bezpośrednim spostrzeżeniom i współprzeżywaniu. Natomiast dla społeczeństwa zmienne jest oddzielenie w drugim człowieku "przeżycia« i »cielesnego ruchu wyrazowego «" (s. 50).

$\mathrm{Na}$ bazie doświadczeń psychicznych (tj. pojawiających się na podstawie wewnętrznego spostrzeżenia własnego lub cudzego przeżycia) budujemy doświadczenie świata. „[T]en kierunek aktów obejmuje [swoją - J.J.B.] "możliwościąu z góry także Ja i przeżywanie innego [człowieka - J.J.B.], dokładnie tak jak moje Ja i przeżywanie w ogóle [przy czym - J.J.B.] obejmuje nie tylko bezpośrednią "teraźniejszość «" (Scheler, 1980, s. 243). Poznanie drugiej osoby nie może przebiegać prawidłowo, jeżeli ten proces nie odbędzie się w sposób spontaniczny (Scheler, 1972, s. 165), na podłożu emocjonalnym. To miłość jest w stanie zwrócić uwagę na drugiego człowieka. Każdy z nas stanowi absolutne indywiduum, będące swoistą wartością - co jest szczególnie cenne dla całego społeczeństwa. Poznanie drugiego człowieka odbywa się poprzez „przeżywanie cudzego przeżywania (Nach-leben) i współprzeżywanie (Mit-liben)" (s. 284-285, tłum. własne). To ukazanie innego wymiaru poznania, w którym zwraca się uwagę na autorefleksję dotyczącą samoświadomości, czyli na to, w jakim zakresie jednostka rozumie sama siebie. Ta świadomość jest warunkiem tego, „aby osoba mogła dać do zrozumienia innej, [...] czym jest to, co myśli, czego nie chce, co kocha" (Scheler, 1980, s. 338). Scheler wskazał na walor autokreacji osoby poznającej, wczuwającej - to akt twórczego rozwoju otwartości na innych. Ograniczeniem naszego poznania jest jedynie miłość, jako głębokie uczucie umożliwiające poznanie innej osoby, które nie będzie jednak nigdy pełne, całkowite.

Poszukiwanie optymalnych możliwości poznania drugiej osoby to zakres zainteresowań Węgrzeckiego (1992). Według niego samookreślający się poznawczo byt „staje się bytem, który nadal określa i samookreśla, ale również jest poznawczo określony i to ze źródła, które znajduje się poza nim. Do wyników samookreślenia mogą dołączyć się rezultaty określenia bytu człowieka przez kogoś innego" (s. 127). To samopoznanie wiąże się z poznaniem drugiego człowieka, który staje się niejako tłem, który zaznacza i odcina byt człowieka - w cudzych manifestacjach człowiek odnajduje odbicie samego siebie. To dzięki kontaktowi z drugim człowiekiem następuje cały proces samopoznania. Będąc więc naukowcem, zainteresowanym poznawaniem innych, sam się kształtuję. Otwartość na innych staje się ubogacającym elementem autokreowania samego siebie. Jak zauważa Węgrzecki, „[B]yt własny człowieka manifestuje się w spotkaniu z drugim na różnych poziomach, zawierających się między biegunami pełni, adekwatności i autentyczności a biegunami niepełności, nieadekwatności i nieautentyczności" (s. 132). Współistnienie, współuczestnictwo stało się w tym wymiarze poznawczym ważne i niczym niezastępowalne: „[D]zięki doświadczaniu możliwym jest więc wgląd w swoisty wymiar bytu ludzkiego, w to, co czyni drugiego człowieka czymś niepowtarzalnym" (s. 132). 


\section{Zmiana podejścia w zakresie poznania osób z zaburzeniami ze spektrum autyzmu}

Wydaje się zasadnym wyjście w tym podrozdziale od określenia, czym jest epistemologia. Otóż to teoria poznania, jako dziedzina zajmująca się poznaniem i wiedzą, wprowadzająca dwojaki sposób poznania (Benton \& Craib, 2003, s. 183-184). Teoria racjonalistyczna opiera się na rozumie (z tego nurtu wywodzą się nauki ścisłe), jako wytworze naszego umysłu - kartezjańskie Cogito ergo sum pozwala na wprowadzenie elementu weryfikacji dotychczasowego poznania.

Drugi nurt - empiryzm - w zdobywaniu wiedzy prymat przyznaje doświadczeniu (por. Hetmański, 2007; Woleński, 2007; Ziemiński, 2001). To podejście wskazuje na różnorodność i specyficzność dokonującego się procesu poznawczego. Zgodnie $z$ tą teorią to indywidualne poznanie powoduje wielość możliwości, sposobów wyjaśniania zjawisk zmysłowych, z pozoru odbieranych jako takie same, sprawiając, iż konieczne staje się poszukiwanie możliwości stworzenia obiektywnego pola poznania. Działania zmierzają do znalezienia regularności w obrębie zjawisk społecznych (Burrell \& Morgan, 1979, s. 7-10). Przykładem to obrazującym może być wyłonienie z badanej przez Leo Kannera grupy dzieci specyficznych cech uznanych za psychozę autystyczną; czy przez Andreasa Retta - specyficznych zachowań występujących u badanych dziewczynek. Odmienne podejście prezentuje Alfred Schütz (2008), który zawraca uwagę na niemożliwość obiektywnego poznania trzeba przeżyć zjawisko społeczne przez uczestniczenie w nim, aby móc je opisać.

Te skrajne podejścia wskazują na poszukiwania pomiędzy obiektywnym i subiektywnym poznaniem. Metafora epistemologiczna, o której mówi Gareth Morgan (1980; 1981; 1983; 2005), jest rodzajem zaangażowania się w życie świata: „Metafory używane są wtedy, kiedy usiłujemy zrozumieć jakiś fragment doświadczanej rzeczywistości za pomocą innego jej fragmentu” (2005, s. 11). Poznanie dokonuje się dzięki metaforom, które mogą stanowić wieloelementowe źródło poznania - na poziomie semantycznym (językowym) czy psychicznym (uzewnętrzniania przeżyć). To Husserlowskie wczucie, bez którego nie ma poznania i Morganowska metafora pozwalają na to, że „[N]asze teorie i wyjaśnienia dotyczące życia organizacji opierają się na metaforach prowadzących nas od widzenia i rozumienia organizacji w sposób charakterystyczny, ale jednak cząstkowy. Metaforę uważa się często po prostu za sposób upiększenia dyskursu, ale jej znaczenie jest o wiele większe. Użycie metafory jest bowiem konsekwencją »sposobu myślenia« $\mathrm{i}$ »sposobu widzenia«, które przenikają nasze rozumienie świata w ogóle" (s. 10-11). Problem subiektywizacji poznania przy pomocy metafor może powodować również zniekształcenia. Morgan przestrzega „jeden z interesujących aspektów metafory polega na tym, że zawsze daje ona... jednostronny pogląd na daną sprawę. Wysuwając na pierwszy plan pewne interpretacje, zmierza do zepchnięcia innych do roli tła" (s. 10-11). 
Pogłębienie zagadnienia poznania osoby z zaburzeniem ze spektrum autyzmu może być dokonane w oparciu o podstawy teorii w nurcie transformacyjno-generatywnym, która została rozwinięta przez George’a Lakoffa, a w szczególności przez ukierunkowanie na zainteresowanie metaforą. Język i poznanie są powiązane ze sobą poprzez wpływanie na siebie. Metafora w ujęciu Lakoffa wpływa na nasz sposób postrzegania, myślenia i działania, jako próba przedstawiania naszych doświadczeń (Lakoff \& Johnson, 2010, s. 7). Przez św. Tomasza z Akwinu duchowość jest przedstawiana metaforycznie w odniesieniu do doświadczeń materialnych, natomiast Clive S. Lewis podkreśla, iż w naszych doświadczeniach odnajdujemy rzeczywistość nie taką, jaką jest obiektywnie, ale jaka ukazuje się w naszym poznaniu. To nasze poznanie, doświadczenie jest kreatorem naszych metafor będących efektem naszego myślenia; kształtowania percepcji / przyjmowania koherentnych systemów pojęciowych opartych na naszym doświadczeniu; kształtowania naszego języka jako narzędzia poznania (Krzeszowski, 2010, s. 9).

Posługiwanie się metaforami pozwala na przedstawianie własnych przeżyć i doświadczeń, które według Lakoffa (Lakoff \& Johnson, 2010, s. 41) mogą mieć charakter strukturalny (kiedy jedno pojęcie nadaje innemu strukturę metaforyczną) lub orientacyjny (ukazujące orientację przestrzenną - ale mające swoje umiejscowienie $\mathrm{w}$ doświadczeniu fizycznym i kulturowym). Ważnym elementem opisywania zjawisk jest otoczenie - kultura, w jakiej dokonuje się opis rzeczywistości: „[N]ajbardziej podstawowe wartości w danej kulturze są koherentne z metaforyczną strukturą najbardziej podstawowych pojęć występujących w tej kulturze" (s. 51). Dzięki metaforom ontologicznym możliwe staje się dokonanie określenia aspektów sytuacji czy zjawisk, określiłbym je jako uogólnienie oraz wyabstrahowanie umożliwiające wyłonienie wiązek, wspólnych elementów, jako metafory dotyczące rzeczy i substancji (np. kwantyfikowanie, uogólnianie celów itd.) (s. 56-58); metafory pojemnika, będące określeniem przestrzeni (s. 60-61); personifikacja (jako nadawanie cech ludzkich przedmiotom fizycznym) (s. 65-66); metonimia (jako nadawanie cech ludzkich zjawiskom, takim jak teorie, choroby) (s. 67). Takie ujęcie wydaje się szczególnie ważne w analizowaniu wypowiedzi osób $\mathrm{z}$ zaburzeniem ze spektrum autyzmu. W rozmowach z nimi mogą być używane metafory, często określane jako komunikat metaforyczny, język metaforyczny.

Przejście od wczucia, społecznego czynnika oddziaływania, poznania w odniesieniu do własnych doświadczeń, do kształtującego poznania bytu drugiego człowieka staje się istotnym modelem spojrzenia na badania nadające drugiej osobie nie tylko charakter przedmiotu czy podmiotu badanego, ale również wpływającego na odmienne spojrzenie na rozumienie - jako auto-wczucia, w ejdetyczno ${ }^{\text {- }}$

${ }^{1}$ Ejdetyka (gr. eidétikós 'idealny', 'formalny'; eídos 'obraz', 'postać', 'wzór') - w fenomenologii wiedza o tym, co istotne; termin ten wprowadził do swojej filozofii Edumd Husserl: fenomenologia według niego ma charakter ejdetyczny, tzn. w nieustannych zmianach zawartości jakiegoś przedstawienia szuka cech stałych, nie bada zjawiska w konkretnym ukształtowaniu, lecz jego istotę; 
-fenomenologicznym ujęciu Husserlowskiego poznania człowieka. Takie podejście powinno charakteryzować nowe spojrzenie na autyzm / zaburzenie ze spektrum autyzmu, odchodzące od oceniania, klasyfikowania czy etykietowania. Dokonywanie ewaluowania i zmian nazw oznaczających nasilone cechy (autyzm, autyzm wczesnodziecięcy, zaburzenia ze spektrum autyzmu), jak również zaliczanie do zakresu terminologicznego (jako choroby, zaburzenia, inności, neuroróżnorodności itd.) stanowi typowy przykład stosowanych metafor - prób jak najbardziej adekwatnych do stanu wiedzy i zakresu prowadzanych analiz określeń. Obecny stan wiedzy przy dokonujących się przemianach społecznych pozwala na weryfikację podejścia i poszukiwania nowego spojrzenia i wprowadzenia nowego zakresu badań dotyczących specyfiki zawartej w określeniu „autyzm” i zachowań prezentowanych przez osoby tak zdiagnozowane.

Zmiana w zakresie percepcji osób z zaburzeniami ze spektrum autyzmu jest warunkiem nadążania za dokonującymi się przemianami w podejściu do tego zaburzenia. Do tej pory społeczeństwo definiowało autyzm / autyzm wczesnodziecięcy na podstawie obserwacji, tworzenia modeli teoretycznych. Sama zmiana nazwy na „zaburzenia ze spektrum autyzmu”, jak również wprowadzenie stopni - głębokości nasilenia występujących specyficznych zachowań (w DSM 5, ICD 11) - wskazuje na konieczność odejścia od pryncypialnego naznaczania, na rzecz poszukiwania nowych spojrzeń, perspektyw inkluzji.

\section{Rozumienie - odbieranie autyzmu / zaburzenia ze spektrum autyzmu}

W procesie badawczym napotykamy na klasyfikacyjne określenia autyzmu, które dotyczą odmienności związanej z występującymi zachowaniami (behawioralnymi). Głównymi elementami opisu są zachowania odbiegające od określonych wskaźników - dotyczące przede wszystkim zachowań społecznych, w tym komunikacyjnych (komunikacji i interakcji społecznych) oraz podejmowanych czynności (i związanych z nimi ograniczeń, powtarzających się wzorców zachowań lub czynności).

Powstałe koncepcje wyrosły na podejściu klinicznym, mającym przede wszystkim wysublimować charakterystyczne objawy pozwalające na ich wyróżnienie, określenie nasilenia i ewentualnych konsekwencji występowania. Podejście takie dotyczy zarówno analizy funkcjonalnej, jak i klinicznej, a celem jest wyjaśnienie odstępstwa od normy. Istotę terminu "norma” definiują słowniki, np. Słownik

Husserl zwykle posługiwał się przykładem trójkąta, którego definicja geometryczna jest niezależna od rozmiarów boków poszczególnych trójkątów (Ejdetyka...). 
języka polskiego podaje: „ilość, miara, granica przewidziana jako wymagana lub obowiązująca w jakimś zakresie" (Norma...). Na pytanie, czy w dzisiejszych czasach potrzebne jest wyznaczanie norm szeroko rozumianych, odpowiada Tomasz Leś (2011): „[o]dpowiadając na zadane w tytule pytanie - czy możliwa jest pedagogika (jako nauka) bez norm? - należy stwierdzić, że nie jest możliwa. Warto jednak dodać, że tak jak trudno uzasadnić to, że pedagogika nie powinna zawierać zdań normatywnych, tak też trudno wskazać konkretny system normatywny, na którym powinna się opierać" (s. 56). Normę w pedagogice, a w szczególności w pedagogice specjalnej, stosujemy nie jako granicę, ale punkt odniesienia. Takie podejście obserwujemy w odniesieniu do wszelkich odstępstw, zarówno do rozwoju człowieka, jak również dysharmonii i występujących deficytów (choćby tylko probabilistycznie).

Odmiennym podejściem jest nurt inkluzyjny, humanistyczny, który pozwala na odwrócenie określenia normy definiowanej przez osoby opisywane. Obecnie, szczególnie w podejściu personalistycznym, podnoszony jest problem świadomości społecznej, jak również samoświadomości poszczególnych członków danego społeczeństwa, zwłaszcza do tej pory odrzucanych, wykluczanych, jak i marginalizowanych, co często prowadziło do pozbawiania ich różnorakich praw i w konsekwencji do powstania idei eutanazji. Dzięki przemianom społecznym, jak również możliwościom wspomnianej inkluzji społecznej, osoby z deficytami (np. osoby z mózgowym porażeniem dziecięcym, autyzmem wysokofunkcjonującym itp.), dotychczas spotykające się z wykluczeniem, znalazły się w kręgu społecznego włączenia. Możliwość nawiązywania kontaktu z tymi osobami, jak również ich efektywność $\mathrm{w}$ strukturze społecznej pozwalają na spojrzenie $\mathrm{z}$ ich perspektywy na dotychczas jednostronnie formułowane twierdzenia i określenia dotyczące zjawiska, jakim jest autyzm.

W odpowiedziach na pytanie Czym jest autyzm? w wywiadzie netnograficznym uzyskano bardzo istotne informacje wymagające zróżnicowania ze względu na wiek, jak również płeć respondentów. Same jednak odpowiedzi układają się w ważne stwierdzenia, jakie dzięki wysyceniu znaczeniowemu można poddać analizie. Wykres 1 przedstawia, jak rozbudowuje się sieć wraz z wiekiem respondentów - niezależnie od ilości osób biorących udział w wywiadzie. We wszystkich przedziałach wiekowych można dokonać podziału na określenia pozytywne, negatywne, jak również niejednoznaczne - często obarczone pytaniem, niepewnością.

Najwięcej formułowanych określeń dotyczących autyzmu ma charakter spersonifikowany i przybiera następujące formy:

- negatywne: zaburzenie, choroba, ograniczenie, utrudnienie, izolacja, brak akceptacji;

- pozytywne: część mnie (tożsamość), wrażliwość, inne zachowanie, akceptacja, sposób rozumienia, odmienność;

- abiwalentne: brak jasnego stwierdzenia, np. nie wiem, trudno powiedzieć, odmienność, cecha. 


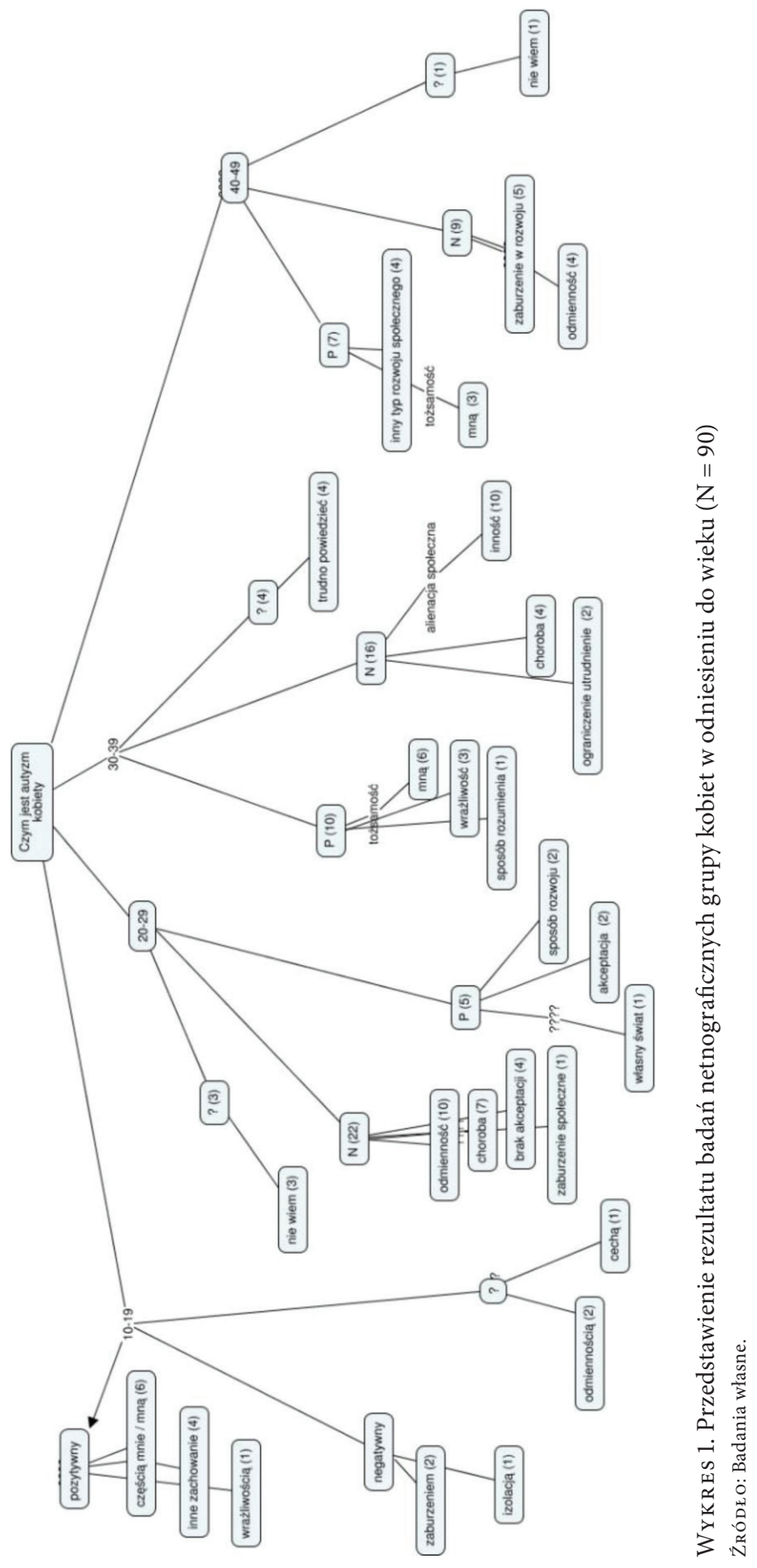




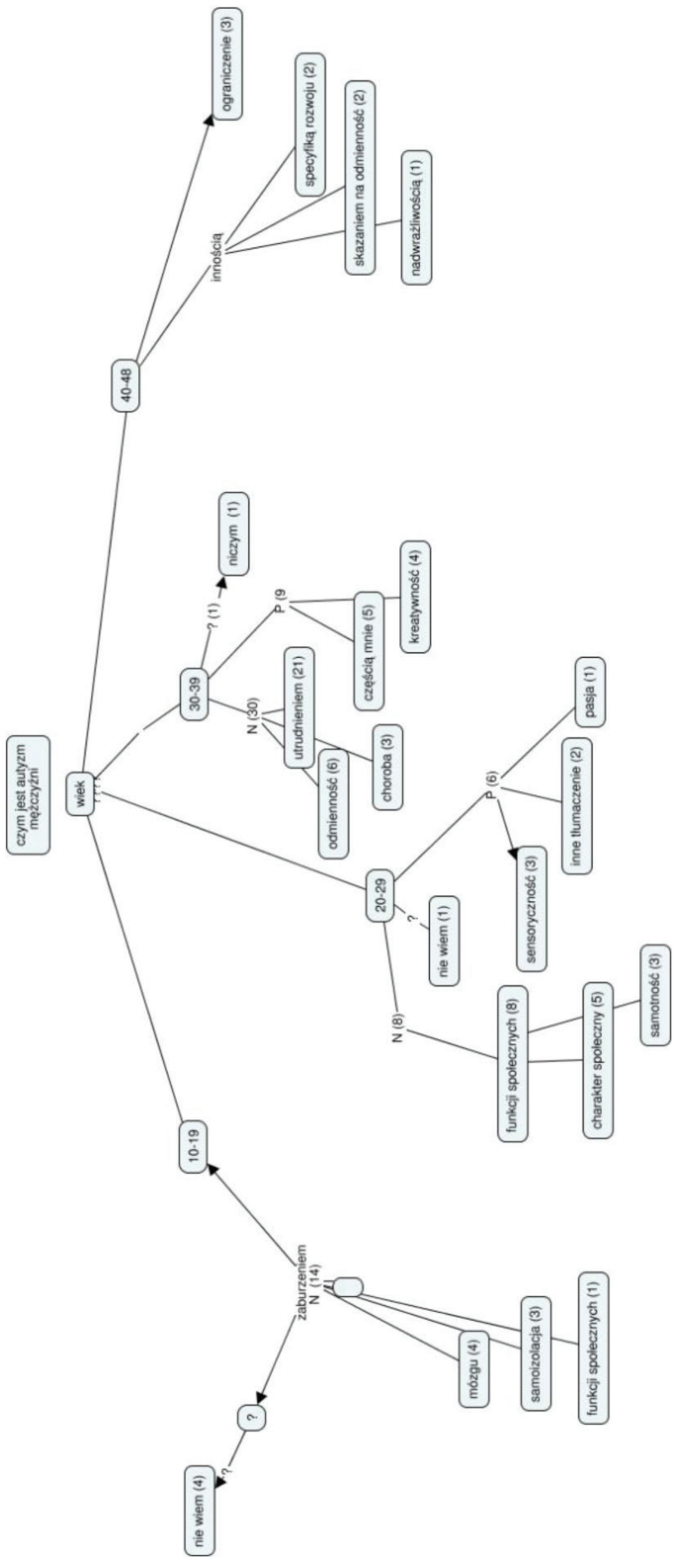

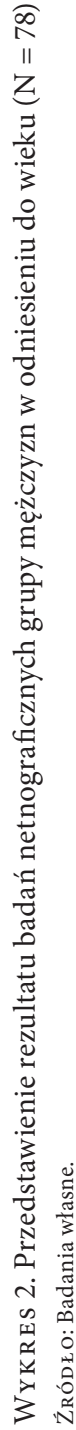


Niewątpliwie ważne jest przedstawienie autyzmu w kontekście społecznym, w jakim najczęściej przebywa osoba z tym zaburzeniem. Szczególnie w określeniach adresowanych do dzieci wskazywane są terminy naznaczające i odróżniające, jak „choroba” czy „zaburzenie”. Stwierdzenia przedstawiane przez respondentów to odbicie postrzegania ich w społeczeństwie przez pryzmat naznaczenia, wyróżnienia w negatywnym tego słowa znaczeniu, jako wynik języka zinstytucjonalizowanego, najczęściej pojawiającego się w ich otoczeniu.

W przypadku mężczyzn we wszystkich grupach wiekowych występują określenia podkreślające ujemne cechy. Najwięcej formułowanych określeń dotyczących autyzmu ma charakter spersonifikowany i są głównie:

- negatywne: zaburzenie, które dotyczy przede wszystkim funkcji społecznych, inność;

- pozytywne: powiązanie z samym sobą (tożsamość), sensorycznością, innym tłumaczeniem, pasją;

- brak jasnego stwierdzenia: nie wiem, specyfiką rozwoju.

Dokonując zestawienia nasilenia występujących stwierdzeń, można przedstawić je w formie uogólnionej jako wynik występujących stwierdzeń w ilości i nasyceniu z podziałem na płeć i wiek. Wiek respondentek stanowi istotny element kształtowania się podejścia do autyzmu. Przede wszystkim występuje negatywna konotacja samego terminu i związanych z nim zachowań nasilających się wraz z wiekiem. Charakterystyczne jest przedstawienie cech opisywanych jako doznanie osobiste do podejścia społecznego, począwszy od wrażliwości parcjalnej, przez społeczny odbiór, do odmienności związanej z indywidualnym rozwojem.

W przypadku mężczyzn charakterystyczne są przede wszystkim stwierdzenia negatywne, ukierunkowane głównie na interakcje społeczne, jak również percepcję napływających bodźców. Wraz z wiekiem obserwuje się ewaluowanie podejścia do autyzmu od społecznego charakteru izolacji w kierunku odniesienia się do własnego doświadczania oraz budowania własnej tożsamości. Wraz z wiekiem obserwujemy dojrzewanie do włączania się w interakcje oraz budowanie na zasadzie dostosowywania się, z zachowaniem odmiennego poznawania. Można wręcz wskazać kierunek dojrzewania społecznego osób przejawiających autyzm, jednak z konotacją negatywną - jako odmienność tkwiącą w nich i niepozwalającą na pełny rozwój społecznego uczestnictwa.

Niezależnie od wieku przeważają najczęściej negatywne konotacje dotyczące autyzmu, jak odmienność, inność, cechy uniemożliwiające pełniejszą konsolidację społeczną. Uwagę zwraca fakt, iż odbierane są one jako cecha osobista, związana z tożsamością, wpływające na percepcję przez społeczeństwo. Analizując nasilenie wybranych określeń, możemy stwierdzić, iż niezależnie od wieku respondentów najbardziej dotkliwe jest dla nich ograniczenie funkcji społecznych (przede wszystkim odbioru). Wtórnie autyzm jest przedstawiany jako odmienność, jednak, co ważne, nie zawsze powiązany z melioratywnym (tylko) odbiorem. 
Analiza uogólnionych wyników z wywiadów obu grup pozwala wskazać kierunek dochodzenia respondentów do różnego postrzegania autyzmu: od odbioru w odniesieniu do doświadczenia społecznego, przez kształtowanie się odbioru w odniesieniu do środowiska, do kształtowania na bazie własnych doświadczeń. W ostatnim przedziale wiekowym widoczne jest ukazanie własnego, tożsamościowego podejścia do autyzmu. Proces taki można określić jako dochodzenie, dojrzewanie do własnego rozumienia i tworzenia już na gruncie społecznym. To przechodzenie można przedstawić jako dojrzewanie do pełniejszego uczestnictwa w życiu społecznym, ale z zachowaniem samoświadomościowego obrazu. Zasadnym w tym miejscu jest odwołanie się do doświadczeń przedstawionych przez Liane Holliday Willey (2018, s. 13), która nazwała ten proces jako „udawanie normalnej” - czyli dostosowywanie się, przeciwdziałanie odróżnianiu się od reszty społeczeństwa.

\section{Podsumowanie}

Przedstawione analizy wskazują na ważny aspekt samoświadomości osób z zaburzeniami ze spektrum autyzmu dotyczący odmienności od reszty społeczeństwa, jak również prób podejmowanych w celu ograniczania tego wyróżnienia/odróżnienia. Jako środowisko zmierzamy, najczęściej przez instytucje, do kształtowania zachowań utylitarystycznych (w skrajnych przypadkach podporządkowania), jak również przewartościowania, nadawania nadmiernego znaczenia indywidualizmowi (często w skrajnym ujęciu) - który w przypadku osób z diagnozą autyzmu może prowadzić do kształtowania poczucia wyjątkowości na tle społecznym. W przypadku przedstawionych badań takie skrajne podejścia są trudne, jak również nie ułatwiają kształtowania się dojrzałej tożsamości społecznej / w społeczeństwie.

Odnosząc się do badań prowadzonych z osobami z zaburzeniem spektrum autyzmu, dotyczącymi samooceny, warto zwrócić uwagę na poszerzanie świadomości związanej z samym spektrum. Badania przeprowadzone przez Robertę A. Schriber, Richarda W. Robinsa i Marjorie Solomon (2014) z 37 osobami dorosłymi z zaburzeniem ze spektrum autyzmu i typowo rozwijającymi się osoba$\mathrm{mi}(\mathrm{N}=50)$ potwierdziły, iż osoby ze spektrum mają wgląd w siebie (posiadają swoją tożsamość) i potrafią zoperacjonalizować swoje doświadczenie społeczne (co wykazały podobne wyniki obydwu grup). Osoby ze spektrum autyzmu są świadome i rozpoznają stany zachowań innych osób i potrafią je definiować jako cechy. Można na tej podstawie potwierdzić zasadność prowadzonych przeze mnie badań; odrzucając brak możliwości prowadzenia takich badań, jak wskazują autorzy, można stwierdzić, „że osoby z autyzmem mają różne cechy osobowości i rozsądny stopień wglądu w ich względną pozycję na tych cechach, z tendencją 
do systematycznego nadużywania swoich ocen. Lepsze zrozumienie osobowości i procesów samooceny u osób z ASD może mieć istotne konsekwencje dla konceptualizacji i leczenia autyzmu, a także dla lepszego zrozumienia interfejsu między osobowością, wglądem w siebie i ogólnie patologicznym funkcjonowaniem" (Schriber et al., 2014).

Celowość wykonywania badań za pomocą wywiadu netnograficznego z wykorzystaniem środków multimedialnych potwierdzili Ellen Kitson-Reynolds, William Kitson i Kevin Humphrys (2015), wskazując na zasadność wykorzystania w komunikacji i nauce środków technicznych - niewymagających bezpośredniego kontaktu (np. twarzą w twarz).

Chciałbym w tym miejscu zwrócić uwagę na przemianę jakościową, jaką powinniśmy wprowadzić w badaniach osób z zaburzeniami ze spektrum autyzmu. Nie spotkałem do tej pory badań, w których pytano by osoby z tym zaburzeniem o to, co rozumieją czy co myślą na temat zdiagnozowanego u nich zaburzenia. Dzięki zastosowaniu badań netnograficznych możemy nie tylko przedstawiać wiedzę o tym, czym jest autyzm, ale wsłuchiwać się w tych, którzy żyją jako tak przez nas nazwani - autystycy.

\section{Bibliografia}

Benton, T., \& Craib, I. (2003). Filozofia nauk społecznych. Od pozytywizmu do postmodernizmu (L. RAsiński, tłum.). Wrocław: Wydaw. Dolnośląskiej Szkoły Wyższej Edukacji TWP.

Burrell, G., \& Morgan, G. (1979). Sociological Paradigms and Organisational Analysis. London: Heinemann.

Ejdetyka. Pobrane z: https://encyklopedia.pwn.pl/haslo/ejdetyka;3896920.html (data dostępu: 7.09.2018).

Hetmański, M. (2007). Epistemologia współcześnie. Kraków: Universitas.

Husserl, E. (1974). Idee czystej fenomenolgii i fenomenologicznej filozofii. Księga druga (D. GIERULANKA, tłum.). Warszawa: PWN.

Kitson-Reynolds, E., Kitson, W., \& Humphrys, K. (2015). Professional normal Living with autism: What's your superpower? A personal reflection. British Journal of Midwifery, 23(11). Pobrane z: https://doi.org/10.12968/bjom.2015.23.11.808 (data dostępu: 12.04.2019).

Krzeszowski, T.P. (2010). Wstęp do wydania polskiego. W: G. Lakoff, \& M. Johnson, Metafory w naszym życiu (T.P. KrzeszowsKI, tłum.). Warszawa: Aletheia.

Lakoff, G., \& Johnson, M. (2010). Metafory w naszym życiu (T.P. Krzeszowski, tłum.). Warszawa: Altheia.

Leś, T. (2011). Filozofia a pedagogika. Czy jest możliwa pedagogika bez norm? Teraźniejszość - Człowiek - Edukacja, 2(54), 47-57.

Morgan, G. (1980). Paradigms, Metaphors, and Puzzle Solving in Organization Theory. Administrative Science Quarterly, 25, 605-622.

Morgan, G. (1981). The Schismatic Metaphor and Its Implications for Organizational Analysis. Organization Studies, 2(1), 23-44. 
Morgan, G. (1983). More on Metaphor: Why We Cannot Control Tropes in Administrative Science. Administrative Science Quarterly, 28, 601-607.

Morgan, G. (2005). Obrazy organizacji (Z. Wiankowska-ŁadyKa, tłum.). Warszawa: PWN.

Norma. Pobrane z: https://sjp.pwn.pl/slowniki/norma.html (data dostępu: 12.04.2019).

Scheler, M. (1972). Die Idole der Selbsterkenntnis. In: Vom Umsturz der Werte. 5. Gesammelte Werke. T. 3. Bern-München: France Verlag 1972.

SCHELER, M. (1980). Istota i formy sympatii (A. WĘGRZECKI, tłum.). Warszawa: PWN.

Schriber, R.A., Robins, R.W., \& Solomon, M. (2014). Personality and Self-Insight in Individuals with Autism Spectrum Disorder. Journal of Personality and Social Psychology, 106(1), 112-130. Pobrane z: https://www.ncbi.nlm.nih.gov/pmc/articles/PMC4122539/\# (data dostępu: 12.04.2019).

Sснütz, A. (2008). Obcy: esej z zakresu psychologii społecznej. W: A. Sснütz, O wielości światów. Szkice z socjologii fenomelogicznej (B. JABŁoŃsKA, tłum., s. 189-201). Kraków: Zakład Wydawniczy Nomos.

Stein, E. (1917). Zum Problem der Einfühlung. Halle: Buchdruckerei des Waisenhauses.

WęGrZecki, A. (1992). O poznaniu drugiego człowieka. Kraków: Wydaw. Naukowe PAT.

Willey, L.H. (2018). Udawanie normalnej. Życie z zespołem Aspergera (zaburzeniami ze spektrum autyzmu) (P. Dobrowolski, tłum.). Kraków: Wydaw. Edukacyjne.

Woleński, J. (2007). Epistemologia: poznanie, prawda, wiedza, realizm. Warszawa: PWN.

Ziemiński, I. (2001). Nowsze koncepcje świadomości w filozofii analitycznej. Filo-sofija, 1, 263-278. 